\title{
Quality of Products of the Wine Sector of the Republic of Moldova - A Stimulation Leverage in Promoting the Image and Ensuring the Export on the Partner Country Markets
}

\author{
Romeo Cereteu \\ romancereteu@gmail.com \\ Elena Timofti \\ e.timofti@uasm.md \\ State Agrarian University of Moldova
}

\begin{abstract}
The quality of agricultural production consists of all the biological, food and technological traits that determine the degree of utility of each type of foodstuff in human food, food industry and other industries, where agricultural production is used as a raw material. Quality can be presented in different ways: political, economic, statistical, legal, sociological, philosophical, etc. The paper presents an analysis of the export of grape wine from the Republic of Moldova to some partner countries. The dynamics, structure, volume and sales incomes, as well as the price for 1 ton of Moldovan wine in relation to CIS countries, the EU and other countries of the world have been studied. The authors emphasize the improvement of the quality and competitiveness of the wine product as a stimulating leverage in promoting image and ensuring export on the market.
\end{abstract}

Keywords: quality, export, market, wine sector, Republic of Moldova.

\section{Introduction}

The quality of production is the appropriation of the products to correspond to the destination for which they were produced (processed), in order to be in accordance with the needs of the consumers. As A. Campeanu mentions, "to work in order to meet consumer needs means to increase the value of the use of products, which is equivalent to the materialized and living growth" [Campeanu A. 2000].

From an economic point of view, the quality of a product is conditioned by the costs related to the qualitative side of satisfying consumer needs, the utility degree of the consumption value, which in the case of grape wine is characterized by the optimal balance between the quality characteristics, such as the main regulated physic-chemical indices and some complementary indices, including: sugar concentration, alcoholic strength, glycerol, mineral substances, various vitamins, etc.

The economic aspect of quality as a category reflects the need for cost accounting not only in the production process, but also in the consumption (processing, exploitation) area.

Starting from the presented above, it results that a product from the grape processing, which is the wine, is characterized by certain biological, technical and economic characteristics, which account and determine its qualitative level. This product, due to its utility, is sold on a market at a certain price.

"The market is seen as a communication channel that generates and disseminates information on price, demand, supply and based on which decisions are made about the fundamental question of the economy: what, how much, how, for whom, and where to produce or to acquire, respectively.

The market represents the dashboard on the basis of which labour, capital, land, investment, innovation, technology and creativity are directed (allocated) in areas and space, depending on social need, price and income levels" [Economy, 2009]. 


\section{Material and method}

In the research, the authors have used the materials of the legislative framework, such as Government Decisions, data from the Ministry of Agriculture, Regional Development and Environment in the field of wine sector development, data of the National Bureau of Statistics of the Republic of Moldova, the National Office of Vine and Wine, and the specialized literature.

The following research methods have been applied during the scientific research process: comparison method, table method and graphical presentation of studied phenomena, average and relative size method, etc.

\section{Results and discussions}

The wine-growing heritage in the Republic of Moldova (in all categories of households) as at 01.01.2017 constituted 135.3 thousand ha. Out of the total area of vineyards, 127.3 thousand ha, representing $94 \%$, are managed by private sector households and $6 \%$ by the public sector. The percentage of bearing fruit vineyards varies between 91.6-95.4\%. The varieties for wine account for $80 \%$. Nowadays, 191 wine factories hold a production license. Wine represents the key product in the category of vine and wine products.

According to Article 2 of the Law no.165 on the amendment of Art. 1 of the Law on Vine and Wine no. 57/2006, the term of "wine" has the following meaning: "wine - a food product obtained exclusively by total or partial alcoholic fermentation of fresh or frozen grapes, pressed or not, or of fresh grape must" [Official Gazette No.109-118 (6032-3041) April 7, 2017].

Wine is the oldest drink created by the hard work of producers. The variety of wines produced in Moldova is very wide and depends on several factors: ecological, biological, technological, quality, composition, etc.

The competitiveness of a product is determined by the totality of consumption and value characteristics that foresees its success on the domestic as well as external market.

Table 1. Export of grape wines from the Republic of Moldova to some partner countries,

\begin{tabular}{|c|c|c|c|c|c|c|}
\hline \multicolumn{7}{|c|}{ 2015-2016 } \\
\hline \multirow{2}{*}{$\begin{array}{l}\text { Partner } \\
\text { country }\end{array}$} & \multicolumn{2}{|c|}{$\begin{array}{c}\text { The volume of the sale, } \\
\text { thousands of liters }\end{array}$} & \multirow{2}{*}{$\begin{array}{c}\text { Growth } \\
\text { (decrease) } \\
\text { rate, } \%\end{array}$} & \multicolumn{2}{|c|}{$\begin{array}{l}\text { Sales revenue, } \\
\text { thousands USD }\end{array}$} & \multirow{2}{*}{$\begin{array}{c}\text { Growth } \\
\text { (decrease) } \\
\text { rate, \% }\end{array}$} \\
\hline & 2015 & 2016 & & 2015 & 2016 & \\
\hline Total & 110857.3 & 130852.9 & 118.0 & 93151.7 & 103761.7 & 111.4 \\
\hline $\begin{array}{l}\text { Including } \\
\text { total CIS } \\
\text { countries, of } \\
\text { which: }\end{array}$ & 66291.8 & 79144.2 & 119.4 & 46167.8 & 47946.7 & 103.8 \\
\hline Belarus & 42882.9 & 40774.2 & 95.1 & 25278.6 & 23621.8 & 93.4 \\
\hline $\begin{array}{l}\text { Russian } \\
\text { Federation }\end{array}$ & 11010.2 & 15819.8 & 143.6 & 8587.7 & 10526.9 & 122.6 \\
\hline $\begin{array}{l}\text { Total EU } \\
\text { countries, of } \\
\text { which: }\end{array}$ & 27920.6 & 31848.7 & 114.0 & 29913.7 & 35316.6 & 118.0 \\
\hline Romania & 7915.2 & 9880.8 & 124 & 5793.9 & 8485.3 & 146 \\
\hline $\begin{array}{c}\text { Czech } \\
\text { republic }\end{array}$ & 7243.7 & 7647.3 & 105.5 & 8002.7 & 8944.0 & 117.0 \\
\hline $\begin{array}{l}\text { Total of other } \\
\text { countries of } \\
\text { the world, of } \\
\text { which: }\end{array}$ & 16644.9 & 19860.5 & 119.3 & 17070.2 & 20498.4 & 120.1 \\
\hline $\begin{array}{l}\text { Taiwan, } \\
\text { Province of } \\
\text { China }\end{array}$ & 2588.7 & 3783.2 & 146.2 & 5890.4 & 8781.8 & 149 \\
\hline Georgia & 11985.6 & 13732.4 & 114.5 & 6766.9 & 6872 & 101.6 \\
\hline
\end{tabular}


Analysis of wine exports from the Republic of Moldova to some partner countries shows that in 2016 compared to 2015 the total volume of sales increased by $18 \%$ and export income by $11.4 \%$, including to the CIS countries by $19.4 \%$ and $3.8 \%$ correspondingly. Exports to Russian Federation are showing an essential growth. Exports to EU countries increased by 14 and 18\%, to Romania - by $24 \%$ and $46 \%$, correspondingly and to other countries - by $19 \%$.

This situation shows that in the analyzed years a slight increase in the volume of exported sales as well as of the export earnings was maintained (Table 2).

Table 2. Structure of exports of grape wine from the Republic of Moldova to some countries

\begin{tabular}{|l|c|c|c|c|}
\hline \multirow{2}{*}{ Partner country } & \multicolumn{2}{|c|}{$\mathbf{2 0 1 5}$} & \multicolumn{2}{c|}{ 2016 } \\
\cline { 2 - 5 } & $\begin{array}{c}\text { Sales volume } \\
\text { structure, } \%\end{array}$ & $\begin{array}{c}\text { Sales revenue } \\
\text { structure, } \%\end{array}$ & $\begin{array}{c}\text { Sales volume } \\
\text { structure, } \%\end{array}$ & $\begin{array}{c}\text { Sales revenue } \\
\text { structure, } \%\end{array}$ \\
\hline Total & 100 & 100 & 100 & 100 \\
\hline $\begin{array}{l}\text { Including total CIS countries, of } \\
\text { which: }\end{array}$ & 59.8 & 49.6 & 63.5 & 46.2 \\
\hline Belarus & 38.7 & 27.1 & 31.2 & 22.8 \\
\hline Russian Federation & 9.9 & 9.2 & 12.1 & 10.1 \\
\hline Ukraine & 7.4 & 5.2 & 15.4 & 9.8 \\
\hline Total EU countries, of which: & 25.2 & 32.1 & 24.3 & 34.0 \\
\hline Romania & 7.1 & 6.2 & 7.6 & 8.2 \\
\hline Czech Republic & 6.5 & 8.6 & 5.8 & 8.6 \\
\hline Poland & 4.3 & 8.0 & 4.2 & 8.1 \\
\hline Germany & 2.4 & 2.4 & 2.0 & 2.0 \\
\hline Slovakia & 1.5 & 2.1 & 0.8 & 1.2 \\
\hline $\begin{array}{l}\text { Total of other countries of the } \\
\text { world, of which: }\end{array}$ & 15.0 & 18.3 & 15.2 & 19.8 \\
\hline Georgia & 10.8 & 7.3 & 10.5 & 6.6 \\
\hline Taiwan, Province of China & 2.3 & 6.3 & 2.9 & 8.5 \\
\hline USA & 0.5 & 1.4 & 0.4 & 1.1 \\
\hline
\end{tabular}

Out of the total amount of wine exports (Table 2), the CIS countries maintained the highest share - 59.8\% in 2015, and in 2016 it increased by 3.7\%, of which the largest importers are: Belarus, Russian Federation and Ukraine.

In the EU countries, the volume of exports accounts $25.2 \%$ and $24.3 \%$ respectively, in 2015-2016. Importers of wines with a weight of 2-7\% each are the following: Romania. Czech Republic, Poland and Germany. The other countries of the world imported from Moldova 15\% of the total volume of sales of grape wine. It is worth mentioning that in 2016 Moldova exported a larger wine volume compared to 2015, but the incomes are lower by $6.6 \mathrm{pp}$. with the CIS countries by $15.3 \mathrm{pp}$ and only with the other countries of the world incomes are higher by $0.8 \mathrm{pp}$.

We export more, but we get less money in return. This situation indicates on the low quality and competitiveness of wine exports to foreign markets. Typically, this is specific for countries that specialize in industry with a low level of modern technology that generates low quality in industry.

In 2016 Moldova exported more than 130 thousand tons of wine in 63 countries worth more than 103760 thousand USD, ranking Moldova 22nd in the world.

The largest importers of Moldovan wine pay the lowest price. The price for Moldovan wine differs depending on the consuming partner country. 


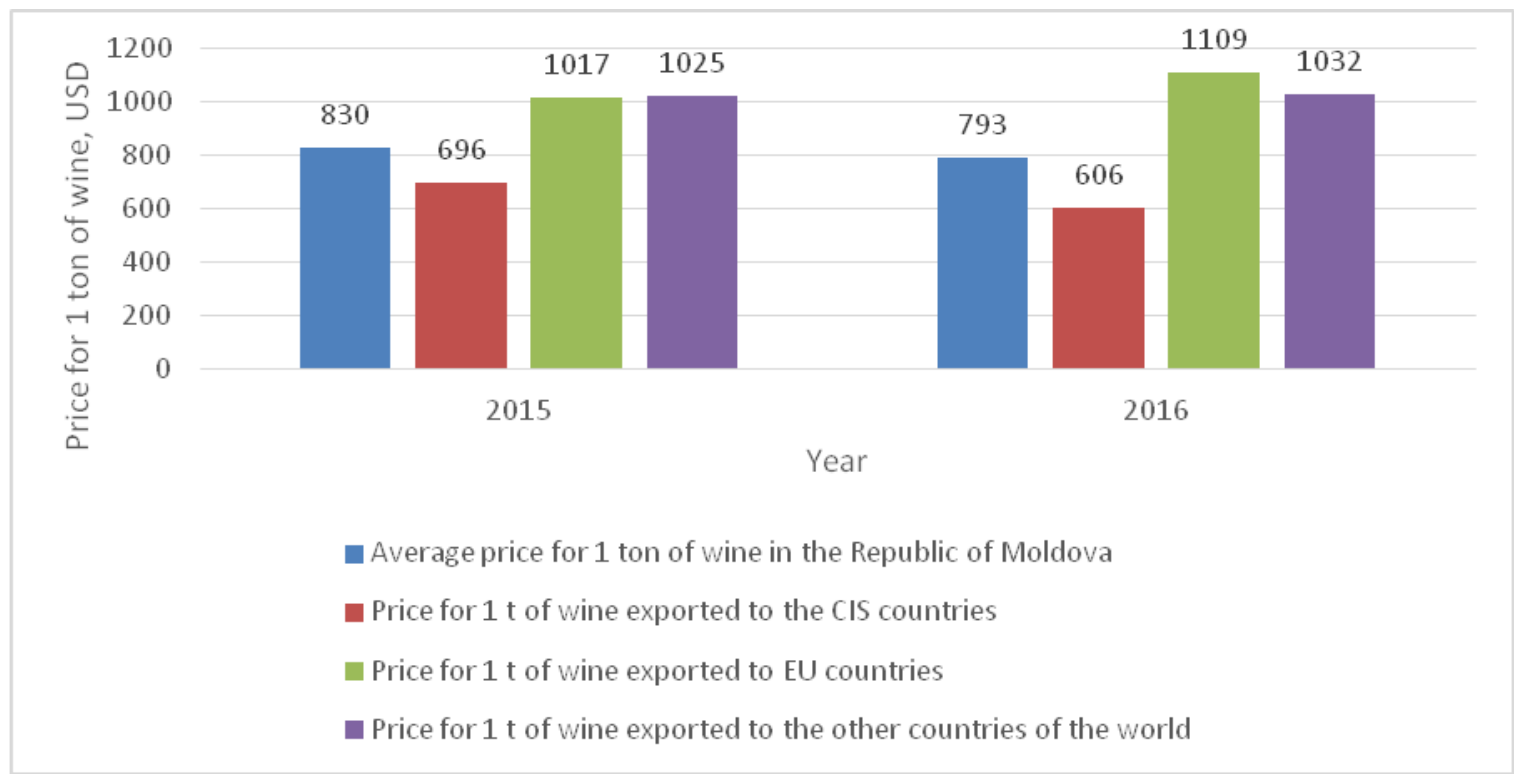

Figure 1. The price for 1 ton of grape wine exported from the Republic of Moldova according to the consuming partner countries

Source: Calculated by authors based on data from table 3 .

Figure 1 data show that in 2016 prices for 1 ton of wine were lower compared to 2015 and only for wines exported to partner countries from the EU it increased by 38 USD per 1 ton of wine.

According to the National Vine and Wine Office, the highest price for 1 ton of wine (in USD) has been paid by: Singapore - 12000; Austria - 6200; South Korea - 4100; Netherlands 2900.

The lowest price for Moldovan wine has been paid by: Georgia - 500; Ukraine - 510; Belarus - 590; Russian Federation - 680; Romania - 870. The quality of the country's products and competitiveness in the foreign markets is low, while the penetration and retention on new markets is modest.

At present, however, the main leverage of the rise in prices for agricultural products and processing industry is still the qualitative factor, which has a major significance in price formation. The need for high-quality products is very important right now. This is the main condition for increasing economic and social efficiency. The level of production quality is an important criterion for the development of any country within the world community and a "business card" for the promotion of products on the world market in the conditions of competition, widening the export possibilities on the world market of goods.

Balancing the content of useful effects (useful substances) in the wine sector products leads not only to increasing the production volumes of consumer goods in the wine industry, but also to reducing production costs while reducing the area of the wine.

In the wine industry, the production of quality wine is directly influenced by the content of sugar, organic and inorganic acids, vitamins A, D, K, B, C, etc. in grapes, and thus by the content of the useful effect in each unit of the product.

The national policy on wine quality has argued the system of geographical indications and protected designations of origin [Government Decision, 2015], in accordance with the requirements of the European Regulations [EC Regulation, no. 492 / 2009; EC Regulation, no. 607/2009]. In this way, the Republic of Moldova was divided into three wine-growing areas for the production of wines with a protected geographical indication "Traian's Wave" in the South Region, "Stefan Voda" in the South-East Region and "Codru" in the Canter Region [MAFI 
Order no. 105 of 11.06.2011]. These geographical indications have been registered in order to be protected at the national level at AGEPI and EU countries by the Producer Associations.

The Ministry of Agriculture, Regional Development and Environment adopted the general objective of modernizing the wine sector, solving structural problems in the wine industry and contributing to the creation of favourable conditions for the production of quality wines (Protected Geographical Indication (PGIs) and Protected Designation of Origin (PDO), thus contributing to increasing competitiveness in the domestic and foreign markets). Already, the number of wine producers with protected geographical indication has reached 40 and the grape producers -30 . At the same time, the share of wine production within typical wine areas is still small, which negatively influences the export of Moldovan wines on the wine markets of the partner countries from east and west. Wine remains one of the few products that are subject to export. Until 2006, the Moldovan wine sector was based on the export of low quality and inexpensive wine. Moldovan wines have failed to restore their previously occupied position on the Russian market. This confirms the impact of the embargo on the import of Moldovan wine. However, the Russian Federation remains the main partner for the Republic of Moldova.

Wine exports to the EU have been neglected and sales have increased only in the last few years by producing high-quality wines, which bear the mark of the wine-growing area. The sensory analysis of wine products is based on the 100-point scale, according to the requirements specified in the Technical Requirements of the Wine Producers Association on the production of wine with Protected Geographical Indication [Technical Requirements].

The raw sparkling wine with "Codrul" PGI named Viorica was rated as an exceptional quality wine with an average mark of 86.6 points, being higher than the admissible minimum score of 78 points, with the following characteristics: clear, light yellow colour with green shades, very complex and intense flavour, fresh, full, harmonious, balanced with typicality of the soil [Ponamariova, 2018. No. 3 [75/2018 p. 35].

It is worth mentioning that within the Expovin-Moldova since 1991, international wine competitions have become history, because already the XXI-st edition took place, where thousands of samples have passed the competition, and 10-30 gold medals, 30-40 silver medals, 10-20 bronze medals were awarded annually, as well as numerous merit diplomas for the impeccable quality of the samples presented. In spite of the difficulties faced by domestic producers, the results obtained promote the image of Moldovan wines and the country far abroad.

\section{Conclusions}

1. The wine-growing heritage in the Republic of Moldova amounts to 135.3 thousand hectares, of which $90 \%$ to $95 \%$ represent bearing fruit vineyards. $80 \%$ belong to wine varieties and 191 of the wine-producing factories hold the production license.

2. Quality includes a whole range of attributes of the product, which determines its usefulness to meet certain needs in accordance with its intended purpose.

3. The main partners of the Republic of Moldova in the wine trade are the CIS and the EU countries, with a weight of $63.5 \%$ and $24.3 \%$, respectively in 2016 . According to the volumes traded in the years 2015-2016, the main export destinations of the Republic of Moldova were Belarus. Russian Federation and Ukraine with a share of total exports of $58.7 \%$. In the trade flow between the Republic of Moldova and the EU there was an increase of the export volume of Moldovan bottled wine to four main trade destinations: Romania, Czech Republic, Poland, Germany, whose share accounts for $19.6 \%$.

4. The price for Moldovan wine differs according to the consuming partner country. The largest Moldovan wine importers pay the lowest price. The main leverage of price increase is, however, the qualitative factor, which has a primordial significance in price formation.

5. Wine companies like: Purcari LLC Winery, Bostovan LLC Winery, Comrat Wines JSC, Traian JSC Winery, etc. were highly appreciated at international competitions with gold, silver, bronze medals and diplomas for the superior quality of fine and noble white, red wines 
with strength of over $12 \%$ volume of alcohol. These obtained results promote the image of Moldovan wines and the country far abroad.

\section{References}

1. Monitorul Oficial al Republicii Moldova nr.366-376 (6761-6771), 28 septembrie 2018, pag.119.

2. Monitorul Oficial art. 2 Legea 165 privind modificarea unor acte legislative nr. 109-118(6032-6041) din 7 aprilie 2017.

3. Hotărârea Guvernului nr.810 din 29 octombrie 2015 cu privire la aprobarea Regulamentului privind modul de evaluare a caracteristicilor organoleptice ale produselor vitivinicole prin analiza senzorială $(M O$ al Republicii Moldova nr.306-310 din 13 noiembrie 2015).

4. Hotărârea Guvernului nr. 356 din 11.06.2015 cu privire la aprobarea Reglementării tebnice "Organizarea pieței vitivinicole". Monitorul Oficial nr. 104-108 din 18.06.2015.

5. Ordinul MALA nr. 105 din 11.06.2011 privind abordarea delimitării ariilor geografice vitivinicole privind producerea vinurilor cu indicație geografică protejată.

6. Câmpeanu A. Statistică-teoretică și economică. Galați: Editura Fundația Academică, 200, pag 142.

7. Caietul de Sarcini privind fabricarea vinurilor cu indicație geografică protejată „Codru " bttp:/ www.db.agei.md/Geoindications/PdfHandler.ash $x ? c x=28$ domain $=1$

8. Economie, ediția a opta - ASE București: Editura Economică, 2009, ISBN 978-709-456-8, 360 p.

9. Legea viei și vinul nr.57 din 10.03.2006 (Monitorul Oficial, 2006, nr.75-78, art.314);

10. Regulamentul (CE) nr.491/2009 al Consiliului din 25 mai 2009 de modificare a Regulamentului (CE) nr.1234/2007 de instituire a unei organiz̧ații comune a piețelor agricole și privind dispoziții specific referitoare la anumite produse agricole (Regulamentul unic OCP).

11. Regulamentul (CE) nr. 607/2009 al Comisiei din 14 iunie 2009 de stabilire a unor norme de aplicare a Regulamentului (CE) nr. 479/2008 din 29 aprilie 2008 al Consiliului in ceea ce privește denumirile de origine protejate și indicațiile geografice protejate, mențiunile tradiționale garantate și prę̧entarea anumitor produse vitivinicole.

12. Ponomariova I. ș.a. Studiul privind compoziția fiæico - chimică și profilul organoleptic al vinurilor albe și roze din Aria de producere IGP "Codru", revista științifică "Pomicultura, viticultura și vinificația nr 3[75] 2018".

13. Vacarciuc L., Vinul: alte vremuri, alte dimensiuni; Compendiu oenologic- Chișinău: s.n,2015 (F.E.-P. „Tipografia centrală”)-608 p. ISBN 978-9975-53-577-9. 